\title{
CILMO - CHILDREN'S INFORMATION LITERACY MODEL ONTOLOGY
}

\author{
KIRINIC, V.; LOVRENCIC, S. \& VIDACEK HAINS, V.
}

Abstract: Information literacy is a field of research that is becoming more and more important. As a part of it, children's information literacy is in the focus of research, as children nowadays start using various technologies in earlier age than before. This paper focuses on children's information literacy model, consisted of four instruments: basic, library, media and technology literacy. Model is represented using formal ontology in Protégé-Frames tool and comprises both the domain knowledge and actual children's information literacy research data. It is shown that in such way information about this research area can be usefully presented with the potential of further development and analysis.

Key words: information literacy, elementary school, children, formal ontology, ontology development
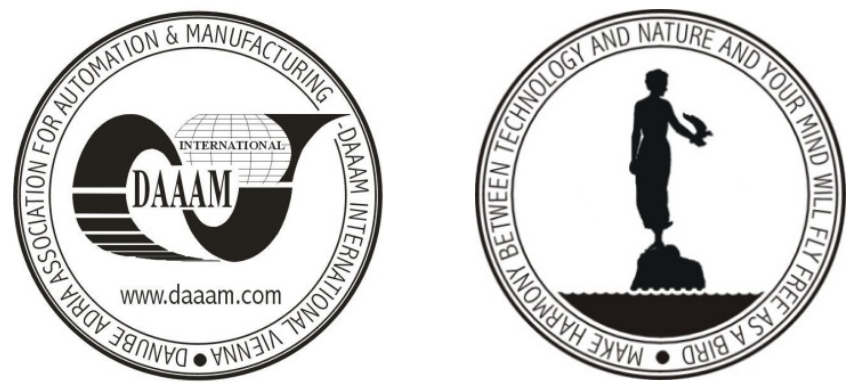

Authors' data: Dr. Ph.D. Kirinic, V[alentina]*; Dr. Ph.D. Lovrencic, S[andra]**; Dr. Ph.D. Vidacek-Hains, V[ioleta ${ }^{*}$, *Faculty of organization and informatics, Varazdin, Croatia, FOI, Pavlinska 2, HR-42000, Varazdin, HR, ** Faculty of organization and informatics, Varazdin, Croatia, K.Filića 10, HR-42000, Varazdin, HR, sandra.lovrencic@foi.hr, valentina.kirinic@foi.hr, violeta.vidacek-hains@foi.hr

This Publication has to be referred as: Kirinic, V[alentina]; Lovrencic, S[andra] \& Vidacek Hains, V[ioleta] (2008). Cilmo - Children's Information Literacy Model Ontology, Chapter 32 in DAAAM International Scientific Book 2008, pp. 371-386, B. Katalinic (Ed.), Published by DAAAM International, ISBN 978-3-901509-66-7, ISSN 1726-9687, Vienna, Austria

DOI: $10.2507 /$ daaam.scibook.2008.32 